\title{
Teaching and Learning: A Journey from the Margins to the Core in European Higher Education Policy
}

\author{
Cristina Sin
}

\section{Introduction}

This chapter analyses how the topic of teaching and learning has evolved in the political discourse of the Bologna Process and of the policy actors who shape European higher education policy. This exercise is particularly stimulating because learning and teaching evolved from a topic of little significance to a forefront concern and a dimension presented as capable of making the difference for the success of the proposed reforms. It is the rise in prominence, the underlying rationales and the dimensions of teaching and learning that the chapter intends to disentangle. Based on an analysis of the central policy documents of the Bologna Process and key reports of other influential supra-national actors, a proposition is put forward that attention to teaching and learning became focal when this dimension began to be perceived as critical to ensure that higher education served the mission assigned to it by policy-makers, primarily of a utilitarian and economic nature. In making this claim, it is suggested that this evolution has been largely determined by the European Commission (EC) and the OECD as prominent supra-national agents and vectors of globalization. The chapter also cautions against the alienation of academics from policy-making which impacts on teaching and learning, an academic territory by excellence.

\footnotetext{
C. Sin $(\square)$

Centre for Research in Higher Education Policies (CIPES), Matosinhos, Portugal

e-mail: csin@cipes.up.pt

A. Curaj et al. (eds.), The European Higher Education Area, 


\section{The Wider Policy Space and the Propagation of Policy Issues}

Although dwelling mainly on teaching and learning as it evolved within the Bologna Process, the chapter acknowledges that the Process has unfolded in a wider context of policy development bearing the imprint of globalization (Amaral and Neave 2009; Grek 2010; Lawn and Lingard 2002; Lingard et al. 2005; Martens and Wolf 2009). Lawn and Lingard (2002) described the emergence of a European policy space in educational governance, while Lingard et al. (2005) argued that globalization and its effects on policy processes have led to the emergence of a global field in education policy, one consequence being that policy text production now reflects the diaspora of policy ideas which circulate rapidly across the globe. For Lawn and Lingard (2002), the construction of a common policy agenda occurs through a new kind of 'magistrature of influence' which assumed two forms: participation in the committees, task-force groups and similar working groups of supranational entities; and dissemination of research studies, reports, and statistics.

The influence of the wider policy context is especially pertinent in the case of the European Commission, given the role it plays in the Bologna Process. The Treaty on the Functioning of the European Union (TFEU) limits the Commission's legal competence in education. Covered by the principle of subsidiarity, education is firmly placed under the competence of member states. Their responsibility 'for the content of teaching and the organization of education systems and their cultural and linguistic diversity' is acknowledged (Article 165 of the TFEU). The Union's contribution is limited to encouraging cooperation between these and to supporting and supplementing their action. Yet, the Commission has indirectly overcome its limited capacity of statutory intervention, exerting influence on European higher education policy by alternative means (see Neave (2005) for a detailed discussion). The Commission's integration in the formal structures of the Bologna Process has given it additional purchase over higher education. Following the invitation to join the Bologna Follow-Up Group in 2001, with equal standing to individual member states, it has greatly determined the direction and progress of the reform. Martens and Wolf argue that the Commission was perceived as a necessary infrastructure and support element, 'like a coat hanger...something to hang the reform on' (Martens and Wolf 2009), therefore instrumental in the promotion of the goals of the Process. Many of the Bologna initiatives have mainstreamed solutions previously developed by the European Commission (e.g. ECTS), while the EC has been providing financial incentives for $\mathrm{HE}$ cooperation and projects in line with the Bologna objectives and has been funding national Bologna promoters, information activities and the ministerial meetings (Keeling 2006). The Commission also funds key stakeholder organizations in the Bologna process (e.g. EUA, ENQA, ESU, etc.). From the standpoint of the Commission, the Bologna Process has been harnessed to serve the agenda of economic growth and international competitiveness outlined in the Lisbon strategy. Thus, despite its initial independence from the Commission, the Process has become increasingly tied into the former's ambitions 
of European integration. For Martens and Wolf (2009), the EU now has more 'options and responsibilities in the field of education policy due to the Bologna Process', a paradoxical development when considered against its initial exclusion. Currently, the Bologna Process is strongly associated with the European Union although its signatory countries go far beyond its territory.

Keeling (2006) claims that the Commission developed an influential discourse on higher education in Europe. It considered higher education as 'purposeful' and 'economically beneficial' for both individuals and society and its activities had to respond to the needs of the labour market and industry. In the context of the Bologna Process, the Commission portrayed learning as an 'inherently productive activity' through which students accumulated and generated knowledge for personal and social benefit. It also promoted the idea that educational activities and outputs were 'measurable', e.g. educational achievements are measured at the level of the individual through ECTS credits (Keeling 2006). The Bologna reforms stood as mechanisms for increasing the employability of university graduates. In fact, as Bologna progressed it placed increased emphasis on the participation of employers in curricular design (Sin and Neave 2014). The utilitarian mission of higher education thus extended into the realm of teaching and learning. Indeed, the Commission's interpretation of higher education's mission as vocational goes back to the 1990s (Neave 2005). For Keeling (2006), the dominance of this interpretation limits alternative understandings of higher educational objectives, such as intellectual development, personal enrichment or the simple satisfaction of curiosity. The Bologna Declaration initially rejected an instrumental view of higher education by presenting it as a vehicle for upholding and promoting European culture. Later on, the London (2007) and Leuven (2009) Communiqués, too, referred to four missions of higher education: preparing students for life as active citizens in a democratic society; preparing students for their future careers and enabling their personal development; creating and maintaining a broad, advanced knowledge base and stimulating research and innovation. Yet, various scholars have noted that the Process has gradually moved from cultural and political rationales to economic ones (Huisman and van der Wende 2004; Tomusk 2004). For Martens and Wolf (2009) this can be attributed to the inclusion of the European Commission into the Process.

For the Commission, therefore, education represents an economic engine, a lynchpin in its strategy of international competitiveness. The advent of globalization saw higher education transformed into a key driver in the knowledge economy, 'the new star ship in the policy fleet for governments around the world' (Olssen and Peters 2005). Concerns with efficiency, results orientation and the achievement of outcomes have come to the fore. As Grek (2010) noted, since 2000 the EC's education policy-making tools have changed, with greater emphasis on indicators and benchmarking, to drive change and push the 'growth and jobs' agenda forward.

The OECD, too, has had considerable impact on the global stage of educational policy. Although its central focus has been 'steadfastly and unwaveringly within the imperium of economics' (Amaral and Neave 2009), education has been consolidating its position among the activities which attracted OECD's attention as an area of application within the overall driving imperative of economics. The effects of 
globalization in education policy have largely been a consequence of the OECD's activities. Its powerful discourse began to influence education in the mid-nineties further to the increasing visibility and credibility of its work on cross-national, comparative educational indicators and statistics (Martens and Wolf 2009). Nowadays, the OECD appears as a trend-setter with an authoritative voice in education policy. In this respect, scholars (Amaral and Neave 2009; Martens and Wolf 2009) have referred to its mode of governance as 'opinion formation'. Grek (2010) claims that the OECD established their authority through the generation and management of sophisticated knowledge, ever more determinant for the orientation of education policy, giving birth to the so-called knowledge politics. She further argues that the policy agendas of the EU and the OECD have been converging, in a union cemented by knowledge and mutual policy learning. The result has been a growing alliance between these two influential actors operating in the European education space, constructing policy problems together, articulating and diffusing new norms and principles (Grek 2010).

Both the EU and the OECD's role in shaping education, its goals and its organization is already acknowledged in policy circles. Their role is mediated by a powerful discourse of globalization, more political than educational, which constructs solutions, produces new conceptual categories or redefines older ones (Lawn and Lingard 2002). The two organizations also coincide in their modus operandi (Amaral and Neave 2009; Grek 2010). In the absence of enforcement tools over member states, persuasion through discourse, networking, soft law and indirect approaches are employed to summon policy consensus and shape opinion favourable to policy-in-the-making when legislative action is not an option (Amaral and Neave 2009).

In the following, attention turns to the emergence and the construction of teaching and learning as a policy problem. An analysis of relevant policy documents has been undertaken in search for the contexts in which teaching and learning has been mentioned, its dimensions, the rationales invoked and the suggested recommendations. Teaching and learning has evolved from a topic of little significance in the early days of the Bologna Process to a forefront concern and a dimension deemed crucial for the success of the intended reforms. The chapter sets out to explore its ascendant trajectory and the likely reasons behind it. It argues that the evolution of this policy issue has increasingly reflected the discourse promoted by the European Commission and by the OECD, resulting in the subordination of teaching and learning to the imperatives of globalization and economy. Under a logic of utilitarianism, performance and efficiency teaching and learning is exhorted to align to market needs and to develop employability/entrepreneurship.

\section{Method}

Documents and reports issued by the main actors on the European educational policy stage represented the source for the analysis of learning and teaching as a policy issue since the inception of Bologna. In the case of the Bologna Process, the 
ministerial communiqués published on the occasion of the biennial summits were perused for references to the topic of learning and teaching. The Standards and Guidelines for Quality Assurance (the current and proposed versions) were also included in the analysis. For the other influential policy actors, the analysis concentrated on documents and reports whose main focus is higher education and/or particularly teaching and learning. For the European Commission, its communications were deemed relevant because they represent the main vehicle for setting out its vision for higher education as a driving force of the economic growth and international competitiveness pursued by the Lisbon strategy. Additionally, a recent report on improving the quality of teaching and learning in Europe's higher education institutions (High Level Group on the Modernisation of Higher Education 2013) was a source for analysis. In the case of the OECD, attention rested on two publications concerned particularly with teaching and learning: Fostering Quality Teaching in Higher Education: Policies and Practices (2012) and Assessment of Higher Education Learning Outcomes (2013). Finally, a European Science Foundation report on the professionalisation of academics as teachers (European Science Foundation 2012) has been subjected to scrutiny. Table 1 lists the texts analysed in this chapter.

Content analysis was performed on the above policy documents. When the texts did not deal exclusively with teaching and learning (e.g. Bologna communiqués or the Commission's communications) analysis sought to identify references to learning and teaching and conjoint terminology (teaching, learning, student-centred learning, learning outcomes, pedagogy, curriculum etc.). Consideration was paid to the context/associations in which these were mentioned and the specific aspects considered. In the case of documents dealing specifically with teaching and learning (or teaching, or learning) the following were considered: rationales for the significance of teaching and/or learning; the dimensions considered under teaching and learning; recommendations on ways of moving forward.

\section{Teaching and Learning as a Policy Issue}

\subsection{Teaching and Learning Elements as Structural Descriptors}

In the early days of the Bologna Process, the preoccupation with teaching and learning was hardly visible. The common degree structure and the tools for degree transparency and comparability (ECTS, diploma supplement, etc.) were the dominant political concern, rendered obvious by the absence of the terms 'teaching and learning' from the first two ministerial communiqués of 2001 and 2003. In both documents, although the term 'learning' appears, it is in relation to lifelong learning. Once in the latter document 'learning outcomes' are mentioned, but unrelated to pedagogy. That the emphasis lay initially on degree structure and its descriptors is especially evident in the textual contexts where 'learning outcomes' 
Table 1 Source documents for the analysis of learning and teaching as a policy issue

\begin{tabular}{|c|c|}
\hline \multirow[t]{9}{*}{ Bologna Process } & Bologna Declaration (1999) \\
\hline & Prague Communiqué (2001) \\
\hline & Berlin Communiqué (2003) \\
\hline & Bergen Communiqué (2005) \\
\hline & London Communiqué (2007) \\
\hline & Leuven Communiqué (2009) \\
\hline & Bucharest Communiqué (2012) \\
\hline & European Standards and Guidelines for Quality Assurance (2005) \\
\hline & $\begin{array}{l}\text { Standards and Guidelines for Quality Assurance in the European } \\
\text { Higher Education Area. Proposal for the revised version (2014) }\end{array}$ \\
\hline \multirow{5}{*}{$\begin{array}{l}\text { European } \\
\text { Commission }\end{array}$} & The role of the universities in the Europe of knowledge (2003) \\
\hline & $\begin{array}{l}\text { Mobilising the brainpower of Europe: enabling universities to make } \\
\text { their full contribution to the Lisbon Strategy (2005) }\end{array}$ \\
\hline & $\begin{array}{l}\text { Delivering on the modernisation agenda for universities: Education, } \\
\text { Research and Innovation (2006) }\end{array}$ \\
\hline & $\begin{array}{l}\text { Supporting growth and jobs - an agenda for the modernisation of } \\
\text { Europe's higher education systems (2011) }\end{array}$ \\
\hline & $\begin{array}{l}\text { Report to the European Commission on improving the quality of } \\
\text { teaching and learning in Europe's higher education institutions (2013) }\end{array}$ \\
\hline \multirow[t]{2}{*}{ OECD } & $\begin{array}{l}\text { Fostering Quality Teaching in Higher Education: Policies and } \\
\text { Practices (2012) }\end{array}$ \\
\hline & $\begin{array}{l}\text { Assessment of Higher Education Learning Outcomes. Feasibility } \\
\text { Study Report (2013) }\end{array}$ \\
\hline $\begin{array}{l}\text { European Science } \\
\text { Foundation }\end{array}$ & $\begin{array}{l}\text { The Professionalisation of Academics as Teachers in Higher } \\
\text { Education (2012) }\end{array}$ \\
\hline
\end{tabular}

appear. Although since 2007 these have also been presented as the embodiment of a new pedagogic approach, in the early days the scarce mentions to learning outcomes came in association with the development of the Framework for Qualifications of the European Higher Education Area (Bergen Communiqué 2005; Berlin Communiqué 2003). For example, the Berlin Communiqué (2003: 4) referred to 'a framework of comparable and compatible qualifications for their higher education systems, which should seek to describe qualifications in terms of workload, level, learning outcomes, competences...'. In brief, at the beginning of the Bologna Process learning outcomes were only addressed as structural descriptors and elements of a common degree framework. A likely interpretation is that, with the realization that ECTS was not a good currency for measuring educational effort, it became necessary to encounter another tool, i.e. learning outcomes, to better define what each teaching module provided.

A brief passing reference to teaching and learning, this time related to pedagogic innovation, first appeared in the 2005 communiqué. Higher education ministers recognized that 'time is needed to optimize the impact of structural change on curricula and thus to ensure the introduction of innovative teaching and learning processes' (Bergen Communiqué 2005). The development of the European 
Standards and Guidelines in Quality Assurance, adopted in 2005, addressed specifically teaching and learning. Beyond the document's self-explanatory purposeensuring and safeguarding the quality of educational programmes through a common European reference framework to build mutual trust, there is hardly any indication that a shift of pedagogic model was already envisaged at the time of its publication. Student-centred learning - as the new pedagogic model came to be conceptualized - is not mentioned at all throughout the document, while learning outcomes appear in three instances in relation to their inclusion in programme design, student assessment and public information of degree programmes. However, the absence of any reference to their pedagogic benefits supports the proposition that early on learning outcomes were merely a descriptor or structural element meant to improve the transparency of educational programmes. Although learning outcomes continued to be portrayed as qualification descriptors, the shifting attention from the structure to the substance of higher education (pedagogy and curriculum) became increasingly evident after 2005 .

\subsection{Teaching and Learning as Pedagogy}

The turning point seemed to have been the 2007 London ministerial summit. From then on, communiqués placed growing emphasis on teaching and learning and advocated a new pedagogic approach-student-centred learning. The London ministerial communiqué testified 'an increasing awareness that a significant outcome of the process will be a move towards student-centred higher education and away from teacher driven provision'. Also, it is here that the relationship between learning outcomes and a new pedagogic approach was first conveyed through the phrase 'student-centred, outcome-based education'.

Student-centred learning kept climbing higher on the political agenda. The Leuven Communiqué (2009) declared student-centred learning and the teaching mission of higher education a priority for the decade to come. Student-centred learning was described as an approach which required 'empowering individual learners, new approaches to teaching and learning, effective support and guidance structures and a curriculum focused more clearly on the learner' (2009: 3). Finally, the 2012 Communiqué reiterated ministerial commitment to student-centred learning. By this time, aware of the problematic enactment of reforms on the shop-floor, ministers emphasized their consolidation and practical implementation, namely 'supporting institutions and stakeholders in their efforts to deliver meaningful changes' (Bucharest Communiqué 2012: 1). One such change regarded learning outcomes, by now viewed as essential to the success of the reforms: 'the development, understanding and practical use of learning outcomes is crucial to the success of ECTS, the Diploma Supplement, recognition, qualifications frameworks and quality assurance - all of which are interdependent' (Bucharest Communiqué 2012: 3). The publication of the report on the assessment of higher education learning outcomes by the OECD at about the same time (2013) is indicative of the 
shared construction of policy problems (Lawn and Lingard 2002). The OECD's rationale was less educational and more concerned with performance, i.e. 'evaluation of instructional effectiveness'. Their report referred to a 'shift away from inputs towards outcome-based notions of higher education throughput' and to the need to 'develop better performance metrics in higher education' (OECD 2013: 3).

Growing acknowledgement of the significance of pedagogic change in parallel to the structural reforms has therefore marked the later part of the Bologna Process. The rise to prominence of pedagogic reform is also evident in the proposed revision of the European Standards and Guidelines (ESG) for Quality Assurance (ENQA et al. 2014). This now includes a standard on 'student-centred learning, teaching and assessment'. A transition is thus obvious from teaching and learning contextualized by structural reform (e.g. learning outcomes as structural descriptors) to teaching and learning in its own right as pedagogy. This transition may be explained by the realization that the key objectives of the Bologna Process and the EHEA could only be achieved if effectively transposed into the everyday practice of lay academics and institutions, into their core activities of teaching and learning. Studies have indeed revealed a mismatch between the remarkable progress at the level of political implementation through regulation on the one hand-whose abundance gave an impression of dynamism and success (Neave 2005) - and the lagging shop-floor enactment of reforms on the other hand (Sin 2012, 2014; Westerheijden et al. 2010):

Attention in the second decade of the Bologna Process needs to turn to the achievement of the substantive, strategic goals more than to further refinement of the architecture. Greater involvement of staff within higher education institutions and other non-state actors may be a key factor for successfully embedding many Bologna action areas in the practice of education (Westerheijden et al. 2010: 9).

Summing up, pedagogic innovation - conceptualized as student-centred learning - made an arguably deferred and sideways entry onto an agenda from which it was initially excluded, concerned solely with the degree architecture and transparency and comparability tools. The curricular dimension emerges, therefore, as secondary, derivative, and instrumental to the achievement of the initial structural dimension (Antunes 2012). Antunes further argued that the so-called 'technical-political instruments' (qualification frameworks, learning outcomes, credits etc.) have been the vehicles to carry the translation of the change agenda from the level of structures to the field of curricular and pedagogic action. These have mediated between dimensions (central political decision-making versus institutional action and educational practice) and between domains (structures and frameworks versus curriculum and pedagogy) of educational action (Antunes 2012).

\subsection{Curricular Review}

As shown, the London Communique (2007) marked the shift of focus from structure to pedagogy. In this same document, ministers underlined 'the importance of curricular reform leading to qualifications better suited both to the needs of the 
labour market and to further study' (2007: 2), while institutions were urged to 'further develop partnerships and cooperation with employers in the ongoing process of curriculum innovation based on learning outcomes' (2007: 6). Furthermore, it is in this same communiqué that globalization is mentioned for the first time. It might not be merely coincidental that pedagogic reform came to the foreground at the same time as employability became a priority, as cooperation with employers arose as a recommendation, and as 'the challenges of the globalized world' were acknowledged in the context of the Bologna Process. In fact, the growing proximity between the Bologna and Lisbon agendas, as well as the force of globalization as a driver for the reform of teaching and learning, emerge clearly from the espoused motivations for the establishment of quality assurance standards:

All over the world there is an increasing interest in quality and standards, reflecting both the rapid growth of higher education and its cost to the public and the private purse. Accordingly, if Europe is to achieve its aspiration to be the most dynamic and knowledge-based economy in the world (Lisbon Strategy), then European higher education will need to demonstrate that it takes the quality of its programmes and awards seriously, and is willing to put into place the means of assuring and demonstrating that quality (ENQA 2005: 9).

From this perspective, curricular and pedagogic reform appear largely justified by an economic rationale, and pursued as a means of increasing higher education's ability to be responsive and contribute to the growth and jobs agenda. Additionally, one of the ESG's fundamental principles is the interests of students, as well as employers and the society more generally, in good quality higher education. This interpretation supports previously mentioned claims that the Bologna Process evolved from a cultural and political rationale in the early days to an economic one (Huisman and van der Wende 2004; Martens and Wolf 2009). However, the Leuven Communiqué (2009: 1) acknowledged the joint mission of teaching and learning, related not only to employability, but also to personal development and active citizenship: 'student-centred learning ... will help students develop the competences they need in a changing labour market and will empower them to become active and responsible citizens'.

As stated earlier, the integration of the European Commission (EC) as a full member in the Bologna Process is likely to have emphasized the economic rationale. The analysis of the topic of learning and teaching in the Commission's communications addressing higher education confirm the supposition that the teaching dimension of higher education is viewed through an economic lens. The mission of teaching is understood as developing graduate skills and competences necessary for a career in a globalized, knowledge-based society. As is the case of higher education as a whole, the teaching dimension is valued for its potential to drive economic development and jobs through an alignment with market demands and cooperation with economic actors. The other missions related to active citizenship education or personal development - present in Bologna's London and Leuven Communiqués - appear to be absent from the four analysed communications of the Commission. It is only in the 2013 report on the modernization of teaching that these values are finally invoked: 
Europe's graduates need the kind of education that enables them to engage articulately as committed, active, thinking, global citizens as well as economic actors in the ethical, sustainable development of our societies (High Level Group on the Modernisation of Higher Education 2013: 13).

Teaching and learning as a theme develops gradually: from teaching mentioned in general terms, to teaching and learning in its curricular dimension, and finally to the development of teaching competence among academics.

In the 2003 communication, teaching was not approached as a topic of its own. Excellence in teaching and research were seen together as means of turning universities into powerhouses 'at the heart of the Europe of knowledge', driving forward economic growth and competitiveness. The economic mission of teaching is obvious in the statement that 'universities train an ever increasing number of students with increasingly higher qualifications, and thus contribute to strengthening the competitiveness of the European economy' (European Commission 2003: 5). In the 2005 communication, the discourse centred on the modernisation agenda, deemed necessary to enable universities to make their full contribution to the Lisbon strategy. Teaching and learning was addressed in its curricular dimension, in one brief instance only. One of the pillars of the modernisation agenda was 'attractiveness to learners', achieved, among others, through 'openness to the world in teaching/learning'. For the EC, this entailed curricular revision capable of responding to the needs of the labour market:

If universities are to become more attractive locally and globally, profound curricular revision is required - not just to ensure the highest level of academic content, but also to respond to the changing needs of labour markets. The integration of graduates into professional life, and hence into society, is a major social responsibility of higher education. Learning needs to encompass transversal skills (such as teamwork and entrepreneurship) in addition to specialist knowledge (European Commission 2005: 5).

It is worth remembering at this point that the principle of subsidiarity protects the content of teaching from the EC's intervention. The topic of curricular revision thus appeared rather audacious. Moreover, the tone got bolder and more specific, recommending that programmes should match the needs of the labour market (European Commission 2006: 3, 5-6), foster entrepreneurship and employability, and that curricula and teaching methods should be directed at the development of employment-related skills:

In order to overcome persistent mismatches between graduate qualifications and the needs of the labour market, university programmes should be structured to enhance directly the employability of graduates and to offer broad support to the workforce more generally. Universities should offer innovative curricula, teaching methods and training/retraining programmes which include broader employment-related skills along with the more discipline-specific skills (European Commission 2006: 6, original emphasis).

The revision of pedagogy to serve the needs of the labour market and to foster employability - through development of transferable skills, involvement of employers or integration of practical experience in courses - was brought up again in 2011. The novelty in these latter communications resided in the recommended 
use of performance indicators (e.g. graduate employment data) in evaluation and, more significantly, of performance-based rewards: 'labour market success should be used as one indicator (among others) of the quality of university performance, and acknowledged and rewarded in regulatory, funding and evaluation systems' (2006: 7) or 'adapting quality assurance and funding mechanisms to reward success in equipping students for the labour market' (European Commission 2011: 5). Justified by a discourse of quality and relevance, the emphasis on indicators, results, measurement and performance - so far mainly applicable to research — appears to have entered the teaching domain as well.

Two additional aspects which fall under teaching and learning were introduced at this point: first, flexible delivery through a variety of teaching modes and exploiting the benefits of ICT; second, the development of teaching competences and raising the status of teaching in higher education. The vision about the former has been recently outlined in a report on New Modes of Learning and Teaching in Higher Education (High Level Group on the Modernisation of Higher Education 2014). It is, however, the latter topic - teaching competences - that has forcefully come into the spotlight not only of the European Commission, but also other organizations. Such attention appears to single out teaching competences as the next dimension in the construction of teaching and learning as a policy problem and the latest burning issue on the political agenda. In fact, it has already been contemplated in the proposed revision of the European Standards and Guidelines for Quality Assurance.

\subsection{Pedagogic Competence and the Professionalisation of Teaching}

Almost a decade ago, Keeling (2006) argued that teaching received little attention in comparison with research in the EC's policy. She claimed that 'the coaching and mentoring role of professors and lecturers, tutors, instructors and supervisors' was 'elided by the dominant discourse' (Keeling 2006: 214). Several years later, teaching competence and the recognition of teaching came under the attention not only of the EC, but also of the OECD and, rather surprisingly, of the European Science Foundation (ESF). It is worth highlighting the remarkable overlap in the dates of the three reports dealing with the topic, all in 2012-2013, which supports the proposition of the shared construction of the policy agenda in the European space (Grek 2010; Lawn and Lingard 2002). In the following, the reasons for its emergence, as well as the recommendations envisaged by policy actors, are explored.

All three reports - by the OECD, the EC and the ESF-approach the topic through the lens of quality. It is argued that quality teaching is 'a sine qua non of a quality learning culture' and that 'the teaching mission should appear as a resounding priority throughout every institution involved in the delivery of higher education' (High Level Group on the Modernisation of Higher Education 2013: 13). Why this sudden preoccupation with teaching quality? A scrutiny of the 
reasons/contexts invoked in support of this new priority area has revealed the following: massification and diversification of student body; capacity of response to economic challenges and better alignment with economic needs; increased competition and reputation-building; accountability and efficiency; individual development and transformation; and the student as a demanding consumer. Although personal growth and civic development still count among the reasons, albeit to a lesser degree and only in the EC and ESF reports, it is mainly economic and accountability rationales that prevail. The hallmarks of globalization are evident in the discourse: institutions now fare in a fast-paced market environment of growing competitiveness, where they must strive to become attractive for a larger and increasingly diverse student body, to satisfy students as fee-paying consumers, under increased pressures for accountability. Their responsiveness to economic challenges - understood mainly as employability and the development of a broad range of skills relevant to the labour market-emerges by far as the most pronounced reason:

Graduates are entering a world of employment that is characterised by greater uncertainty, speed, risk, complexity and interdisciplinary working... University education, and the mode of learning whilst at university, will need to prepare students for entry to such an environment, and equip them with appropriate skills, knowledge, values and attributes to thrive in it (Hénard and Roseveare 2012: 8).

A less common but important point is made by the ESF in relation to the economic benefits of quality teaching. In its view, quality teaching is conducive to an optimal use of research for the benefits of the outside world. That is, equipping scientists with state-of-the-art insights on teaching will allow leveraging the knowledge embedded in their research, which can be expected to increase the return on investment in science (European Science Foundation 2012: 5).

Quality teaching is equated with student-centred approaches and the pursuit of student-centred learning, as was also the case in the Bologna Process discourse. According to the OECD report, the complexity and uncertainty of society and the economy and the need for continuous adaptation entail that 'higher education can no longer be owned by a community of disciplinary connoisseurs who transmit knowledge to students... In practice, institutions will have to learn how to best serve the student community. Students have become the focal point of the learning approach in many areas of the world' (Hénard and Roseveare 2012: 9). Yet, all documents unanimously lament the persistence of what they present as outdated teacher-centred pedagogic styles. For instance the ESF report states that:

...in much of Europe, academics continue to rely on their own student experience when teaching. This reinforces subject- and teacher-centred approaches that do not stimulate desired high-quality learning experiences or the kinds of outcomes required by the new European social and economic context (European Science Foundation 2012: 8).

The three reports coincide to a great extent in the recommendations that they put forward to improve teaching quality, mainly around developing teaching competences and raising the status of teaching. The difference between them lies in the scope of recommendations. The OECD report targets specifically education 
institutions and suggests measures which can be taken at this level, such as elaborating institutional strategies and frameworks for teaching quality, fostering leadership for teaching quality, adapting other institutional policies in this respect (e.g. human resources, student support etc.), encouraging innovation, etc. The other two reports have a wider scope, with recommendations for institutional, national and European levels. For instance, they both highlight the importance of dedicated funding to improve teaching and learning and of dedicated support for capacity-building (educational development) at all policy-making levels. Additionally, the report to the European Commission contemplates several measures beyond those related to the pedagogic development of teaching staff and the valorisation of teaching. These concern: the consideration of student feedback in order to improve teaching and learning; the curriculum, elaborated in partnership with students and employers; student counselling, guidance, mentoring and tracking; or cross- and trans-disciplinary teaching and learning.

Despite some differences, the bulk of recommendations in the three reports addresses the following:

- awareness-raising of teaching quality and celebration of teaching excellence through reward and recognition

- parity of esteem between teaching and research and valorisation of the scholarship of learning and teaching (ESF puts forward the concept of teacher-researcher)

- improvement of pedagogic competences for teaching staff through continuous professional development.

The utmost importance attributed to pedagogic competence is signalled by the ESF recommendation regarding the definition of professional standards for higher education teachers. This is echoed by the recommendation in the EC report that all staff teaching in higher education should have received certified pedagogic training by 2020 and that continuous professional development should be made a requirement. ${ }^{1}$ The high priority assigned to teaching competence is also visible in the recommended establishment of a European Academy for Teaching and Learning by the EC report, or the European Forum for higher education teacher development proposed by the ESF. Moreover, according to the ESF, the success of the Bologna Process objectives and of the EHEA is conditioned by the pursuit of the above measures:

Establishing professional standards for higher education teaching across Europe, the introduction of student-centred teaching, and the preparation of academics to fulfil these requirements are important steps to achieve these aims. So far, European policies have rarely affected the quality of teaching at the classroom level (European Science Foundation 2012: 9).

\footnotetext{
${ }^{1}$ Universities in the UK already require pedagogic qualifications and CPD as condition for employment. For more details see the UK Professional Standards Framework https://www. heacademy.ac.uk/professional-recognition/uk-professional-standards-framework-ukpsf.
} 
This new emphasis on developing academics' teaching competences appears to have already made inroads in the Bologna Process developments. The proposed revision of the ESG for Quality Assurance (ENQA et al. 2014) marks a significant change of focus from the initial one: quality assurance of teaching staff has been replaced by development of teaching staff in the new version. The latter is reinforced as a duty for HEIs, as is the due recognition of teaching not only through development opportunities, but also teaching-based awards and promotion. Let us briefly remember the proposition of a shared European (and global) political space, in which the OECD and the EC increasingly connect their agendas in a mutual process of policy learning and joint construction of policy issues (Grek 2010). This, coupled with the fact that the Bologna Process has been harnessed in the pursuit of the Commission's Lisbon strategy, enable the supposition that teaching competence and the professionalisation of teaching staff will eventually make their way onto on the agenda of the Bologna Process.

\section{Conclusions}

The chapter has analysed the evolution of teaching and learning in the policy discourse of the Bologna Process and of other key policy actors shaping the European higher education policy agenda (the EC, the OECD and the ESF). It has shown that from a low-profile issue on an agenda dominated by structural reform at the turn of the century, teaching and learning started to be approached around 2007, conceptualized in a new pedagogic model: student-centred learning. It suggested that this occurred further to the realization that the achievement of the EHEA depended on shop-floor enactment and change in academic and institutional practices, ultimately of a pedagogic nature. In parallel to the promotion of student-centred learning, curricular reform came in the spotlight. The discourse centred on its tuning and responsiveness to labour market needs. The latest dimension of teaching and learning to have drawn policy-makers' attention has been the teaching competence of academic staff, deemed unsuitable for the kind of pedagogy required by the changed operational environment of institutions: global competition for students, massive and diversified student body, more demanding students assuming a consumer posture, concerns with efficiency, performance and accountability, etc.

Primarily economic rationales, driven by the imperatives of globalization, are argued to have underpinned the rise to prominence and evolution of teaching and learning on the political agenda. This suggests that, contrary to the Anglo-Saxon tradition in which improvement and innovation in teaching and learning have traditionally been pursued in the name of the student experience, the teaching and learning agenda promoted by supra-national European policies has been shaped less by educational concerns, and more by a utilitarian view of higher education as a key element in a strategy of economic growth and competitiveness, in the face of the challenges of globalization. 
Scholars have claimed that Bologna has gradually downplayed cultural and political rationales, embracing economic ones instead (Huisman and van der Wende 2004; Martens and Wolf 2009). This chapter purports that the 'magistrature of influence' (Lawn and Lingard 2002) operated by prominent transnational actors obeying the logic of globalization has been decisive in this evolution of policy. The European Commission comes first to mind given its member status in the Bologna Process. But the OECD's authority is not to be discounted. It acts as a trend-setter, and it already shapes the European Commission's agenda through what (Grek 2010) referred to as knowledge politics and mutual policy learning. Rather surprisingly, these organizations' influence has now reached a domain of academic competence by excellence: teaching and learning. Thanks to the two organizations' ability of 'opinion formation' (Amaral and Neave 2009), the professionalisation of teaching staff — hot on the political agenda of both — is likely to climb high among the priorities of the Bologna Process.

By way of a final remark, we recall that already a decade ago, Neave (2005) noted in relation to Bologna that 'the ghost of academia' was 'largely absent from the feast'. The Bologna follow-up group (BFUG) currently includes all the signatory members of Bologna and the European Commission, as full members, and the Council of Europe, the EUA, EURASHE, ESU, UNESCO, Education International, ENQA and Business Europe, as consultative members. While the EUA represents the rectors of European universities, EURASHE the presidents of European polytechnics, ESU the European students, ENQA the European quality agencies and Business Europe the European entrepreneurial estate, the representation of academics has been delegated to Education International, a worldwide federation of unions representing teachers and education employees across the globe. Therefore, European academics have been conspicuously absent from the structure in charge of overseeing the Bologna process between ministerial meetings, their presence being mimicked by what is not even a European institution, whose participation is diluted by much larger numbers of other education professionals. Because teaching policies enter deep onto academic territory and competence, a word of caution against having academics as 'the great absent' from policy-making becomes pertinent once again. As research has already shown, there is in general a profound ignorance among academics about the implementation of Bologna and its intricate policy developments.

Acknowledgement This work has been funded by a post-doctoral fellowship (SFRH/BPD/85724/2012) awarded by the Foundation for Science and Technology (FCT) in Portugal financed by the QREN/POPH Programme, the European Social Fund (ESF) and national funds from the Ministry of Education and Science (MEC).

Open Access This chapter is distributed under the terms of the Creative Commons Attribution Noncommercial License, which permits any noncommercial use, distribution, and reproduction in any medium, provided the original author(s) and source are credited. 


\section{References}

Amaral, A., \& Neave, G. (2009). The OECD and its influence in higher education: A critical revision. In A. Maldonado \& R. Bassett (Eds.), International organizations and higher education policy: Thinking globally, acting locally (pp. 82-98). London: Taylor \& Francis.

Antunes, F. (2012). 'Tuning' education for the market in 'Europe'? Qualifications, competences and learning outcomes: Reform and action on the shop floor. European Educational Research Journal, 11(3), 446-470.

Bergen Communiqué. (2005). The european higher education area-Achieving the goals. In: Communiqué of the Conference of European Ministers Responsible for Higher Education, Bergen.

Berlin Communiqué. (2003). Realising the european higher education area. In: Communiqué of the Conference of Ministers responsible for Higher Education, Berlin.

Bologna Declaration. (1999). The Bologna Declaration of 19 June 1999. Joint declaration of the European Ministers of Education. Bologna.

Bucharest Communiqué. (2012). Making the most of our potential: Consolidating the European higher education area. Bucharest.

ENQA. (2005). Standards and guidelines for quality assurance in the European higher education area. Helsinki: European Association for Quality Assurance in Higher Education.

ENQA, EUA, EURASHE \& ESU. (2014). Standards and guidelines for quality assurance in the European higher education area. Proposal for the revised version submitted to Bologna Follow-Up Group.

European Commission. (2003). The role of the universities in the Europe of knowledge. Brussels: European Commission.

European Commission. (2005). Mobilising the brainpower of Europe: Enabling universities to make their full contribution to the Lisbon Strategy. Brussels: European Commission.

European Commission. (2006). Delivering on the modernisation agenda for universities: Education, research and innovation. Brussels: European Commission.

European Commission. (2011). Supporting growth and jobs-An agenda for the modernisation of Europe's higher education systems. Brussels: European Commission.

European Science Foundation. (2012). The professionalisation of academics as teachers in higher education. European Science Foundation: Science Position Paper. Strasbourg.

Grek, S. (2010). International organisations and the shared construction of policy 'problems': Problematisation and change in education governance in Europe. European Educational Research Journal, 9(3), 396-406.

Hénard, F., \& Roseveare, D. (2012). Fostering quality teaching in higher education: Policies and practices. An IMHE guide for higher education institutions. Paris: OECD.

High Level Group on the Modernisation of Higher Education. (2013). Report to the European Commission on improving the quality of teaching and learning in Europe's higher education institutions. Luxembourg: Publications Office of the European Union.

High Level Group on the Modernisation of Higher Education. (2014). Report to the European Commission on new modes of learning and teaching in higher education. Luxembourg: Publications Office of the European Union.

Huisman, J., \& van der Wende, M. (2004). The EU and Bologna: Are supra- and international initiatives threatening domestic agendas? European Journal of Education, 39(3), 349-357.

Keeling, R. (2006). The Bologna Process and the Lisbon research agenda: The European Commission's expanding role in higher education discourse. European Journal of Education, 41(2), 203-223.

Lawn, M., \& Lingard, B. (2002). Constructing a European policy space in educational governance: The role of transnational policy actors. European Educational Research Journal, 1(2), 290307. 
Leuven Communiqué. (2009). The Bologna Process 2020-The European Higher Education Area in the new decade. In: Communiqué of the Conference of European Ministers Responsible for Higher Education, Leuven.

Lingard, B., Rawolle, S., \& Taylor, S. (2005). Globalizing policy sociology in education: Working with Bourdieu. Journal of Education Policy, 20(6), 759-777.

London Communiqué. (2007). Towards the European higher education area: Responding to challenges in a globalised world, London.

Martens, K., \& Wolf, K. D. (2009). Boomerangs and Trojan horses: The unintended consequences of internationalising education policy through the EU and the OECD. In A. Amaral, G. Neave, C. Musselin, \& P. Maassen (Eds.), European Integration and the Governance of Higher Education and Research (pp. 81-108). Dordrecht: Springer.

Neave, G. (2005). On snowballs, slopes and the process of Bologna: Some testy reflections on the advance of higher education in Europe. Paper presented at the Background paper for presentation at ARENA, University of Oslo.

OECD. (2013). Assessment of higher education learning outcomes. Feasibility study report. Paris: OECD.

Olssen, M., \& Peters, M. A. (2005). Neoliberalism, higher education and the knowledge economy: From the free market to knowledge capitalism. Journal of Education Policy, 20(3), 313-345.

Prague Communiqué. (2001). Towards the European Higher Education Area. Communiqué of the meeting of European Ministers in charge of Higher Education in Prague on May 19th 2001. Prague.

Sin, C. (2012). Loose Policy and Local Adaptation: A Comparative Study of Master Degrees in the Context of the Bologna Process. Lancaster University.

Sin, C. (2014). Lost in translation: The meaning of learning outcomes across national and institutional policy contexts. Studies in Higher Education, 39(10), 1823-1837.

Sin, C., \& Neave, G. (2014). Employability deconstructed: Perceptions of Bologna stakeholders. Studies in Higher Education. doi:10.1080/03075079.2014.977859

Tomusk, V. (2004). Three Bolognas and a Pizza Pie: Notes on institutionalization of the European higher education system. International Studies in Sociology of Education, 14(1), 75-95.

Westerheijden, D., Beerkens, E., \& Cremonini, L. (2010). The Bologna Process independent assessment. The first decade of working on the European Higher Education Area. Germany: Cheps, Incher-Kassel, Ecotec. 